\title{
Foreign Entry Modes as a Function of Age among Small Businesses in Kampala, Uganda
}

\author{
Olutayo K. Osunsan ${ }^{1}$, Wandiba Augustine ${ }^{2}$, Patricia Abiria ${ }^{3}$, Susan Busingye ${ }^{4}$, \\ Irau Florence 5 \\ ${ }^{1}$ Lecturer, Department of Business \& Management, College of Economics \& Management (CEM), Kampala \\ International University, Uganda. \\ ${ }^{2}$ Lecturer, Department of Human Resources \& Supply Management, CEM, Kampala International University, \\ Uganda. E-mail: wandibaa@yahoo.com \\ ${ }^{3}$ Lecturer, Department of Human Resources \& Supply Management, CEM, Kampala International University, \\ Uganda. E-mail: patandama@gmail.com \\ ${ }^{4}$ Lecturer, Department of Human Resources \& Supply Management, CEM, Kampala International University, \\ Uganda. E-mail: busingyesusan63@yahoo.com \\ ${ }^{5}$ Lecturer, Department of Accounting \& Finance, CEM, Kampala International University, Uganda.
}

\begin{abstract}
The study explored the influence of the firm's age on choice of internationalization mode in Kampala, Uganda. Testing four (4) hypotheses: (i) There is no significant difference between firm age and level of exporting, (ii) There is no significant difference between firm age and level of licensing, (iii) There is a significant difference between firm age and level of joint ventures, and (iv) There is a significant difference between firm age and level of foreign direct investments. Using a sample of 409 small businesses, the data was analyzed with the application of range, means, standard deviations, Analysis of Variance (ANOVA). The study found that the first two hypotheses were accepted, while the last two were reject. The conclusion was down that small businesses might not have the resource to commitment to high levels of internationalization along the 'establishment chain' and thus the recommendations were give that small businesses should be encouraged to internationalize for the sake of their wellbeing and to engage partnership/collaborations to enable them adopt higher levels of the establishment chain.
\end{abstract}

Keywords - Internationalization, Firm Age, Small Scale Enterprise, Uganda. JEL: M10, M16, L21, L26

\section{INTRODUCTION}

Internationalization is the process of escalating the accumulation of knowledge in markets and institutions overseas. Internationalization can be seen as a part of the continuous strategy process of most businesses and takes place over time (Jones \& Coviello, 2005). It has been noted that most businesses initiate the internationalization process by exporting to culturally parallel countries, influenced by psychic distance and/or cultural distance (Sousa \& Tan 2015). Scholars (Sharma \& Blomstermo, 2003) argue that the longer a firm takes to engage international behavior, the more complicated it will be to navigate and flourish internationally. Internationalization can open up new markets, profit opportunities, growth opportunities and ensure longevity of businesses, more so in the case of small businesses (Kontinen \& Ojala, 2010; Daszkiewicz \& Wach, 2014; Osunsan \& Nowak, 2015).

International entry mode research is essential since the entry mode adopted by a business has significant implications on performance of the business (Brouthers, 2002). This choice can determine whether a business has complete control over the foreign unit or has to split control with a partner or partners (Arregle et al., 2006). Once adopted, the mode of entry is hard to modify, due to the fact that it has long-term ramification for the business (Brouthers \& Hennart, 2007). This importance is underpinned by the various empirical studies to explore the entry mode decision (Brouthers \& Hennart, 2007; Canabal \& White, 2008).

The foreign market entry mode decision is a vital strategic choice ( $\mathrm{Lu}, 2002)$, especially for small business. It dictates the business' level of resource commitment to the foreign market (Hill, Hwang, \& Kim, 1990), the risks the firm will bear in the host country (Hill et al., 1990), and the nature of control a firm can exercise over its foreign activities (Arregle et al., 2006). Unlike their big and multinational counterparts, small businesses differ in a variety of aspects, which impacts all decisions including managerial, and, eventually the method internationalization that is adopted (Maekelburger, Schwens \& Kabst, 2012). The intricacies of small business and the consequences of their characteristics, calls for the investigation of small business foreign market entry mode choice behavior (Brouthers, Brouthers, \& Werner, 1996). This paper therefore concentrates 
on market entry mode, because one of the critical decisions in the internationalization process is the choice of an entry strategy into a foreign market (Quer, Claver and Andreu, 2007). More specifically it looks at the various entry modes and tries to see if firm age plays a role in the choice of foreign market entry mode. This study therefore sought to test four hypotheses on the difference of firm age on exporting, licensing, joint ventures and Foreign Direct Investment (FDI). Firm age was captured in groups as: (1) age $<5$ years, (2) age $\geq 6$ but $<10$, (3) age $\geq 11$ but $<15$, (4) age $\geq 16$ but $<20$, (5) age $\geq 21$ but $<25$, and (6) age $\geq 26$. Though there are several foreign market entry mode, this study focuses on the four main aspects as portrayed in figure 1 .

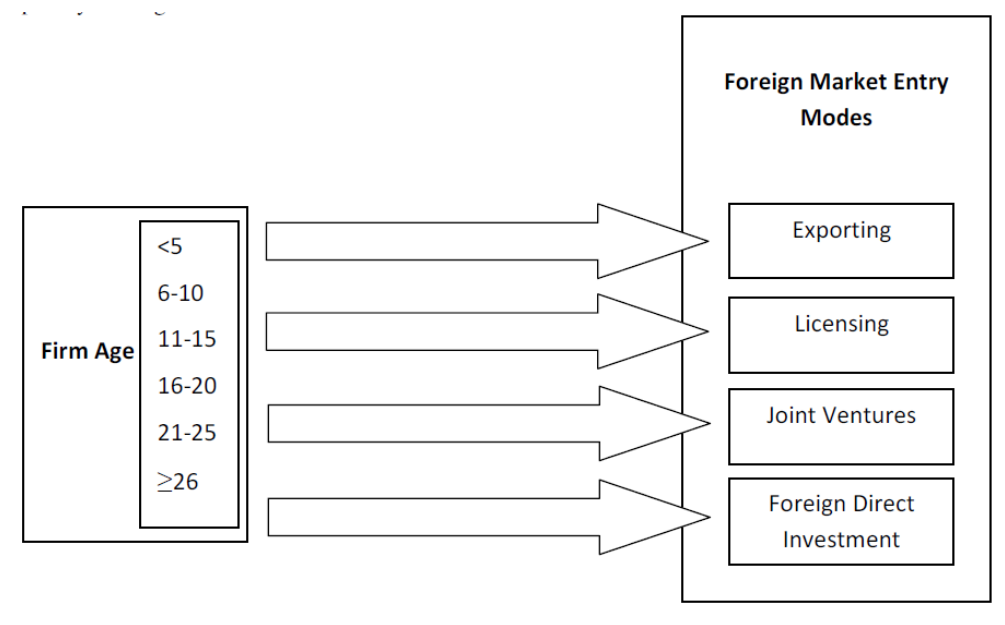

Figure 1: Research Model

\section{LITERATURE REVIEW}

\subsection{Foreign Market Entry Mode}

Leih and Teece (2014) pointed out that foreign market entry modes or strategies refer to a business's goals, plans and decisions in regard to which foreign market to enter, when to enter, and how to enter. Foreign entry strategy is the way used by a firm to start doing business in a foreign country (Shama, 2000); it is a business's attempt or drive that makes possible the entry of firm's products, technology, human skills, or other resources into a foreign country (Karkkainen, 2005). The many forms of market entry strategy can be categorized between equity and non-equity modes. Equity modes involve firms taking some measure of ownership of the foreign based business, such as wholly owned subsidiaries and joint ventures. Non equity modes do not involve ownership and include exporting or some form contractual agreements such as licensing (Wilkinson \& Nguyen, 2003). Cateora and Graham (2002) suggested that there are six basic strategies for entering a new market: export/import, licensing and franchising, joint venturing, consortia, partially-owned subsidiaries, and whollyowned subsidiaries. Generally, these represent a continuum from lowest to highest investment and associated risk-return potential. The different market-entry strategies can be summarized according to Michalski (2015) as follows:

1. Exporting can be defined as the marketing of goods produced in one country into another; it is the conventional and well well-known form of operating in foreign markets. Though no direct manufacturing is a necessary in an overseas country, considerable investments in marketing are essential. Exporting provides the lowest risk and swiftest entry to the host country (Sousa \& Tan, 2015). It has been cited as the most commonly used initial mode of internationalization by businesses.

2. Licensing is a contractual arrangement whereby one enterprise is given the right to partners, trademarks, know-how, and other intangible assets by its owner in return for a royalty or a fee. Licensing provides a low-risk, quick, and capital free entry to the host country. The two companies share ownership, control, and profits of the entity. A franchise is a form of licensing agreement.

3. A joint venture, often called a strategic alliance, is a form of partnership which involves investment by both foreign enterprises and/ or local enterprises to create a new entity. Joint ventures are popular because one enterprise may not have the necessary financial, technical, or managerial resources to enter a market alone. This approach also often ensures against barriers being imposed on the foreign company by the government of the host enterprise.

4. Foreign direct investment used to involve an enterprise investing in building or upgrading a factory in another country (Kotler and Keller, 2006). Currently it has been expanded to include the acquisition of a controlling interest in a company in another market. There are several ways in which an enterprise can 
invest directly in foreign markets: (i) construction of facilities or investment in facilities in a foreign market;

(ii) mergers and acquisitions; (iii) investment in a joint venture located in a foreign market.

Once a firm decides to enter an international market it must choose an appropriate form of operation or entry mode (Nakos \& Brouthers, 2002). Firms can select among several modes of foreign entry, including exporting, contractual agreements (e.g., licensing), joint venturing, acquiring an existing company, and establishing a wholly-owned Greenfield investment from scratch (Michalski, 2015; Pan \& Tse, 2000). However each made has its resources implications on the firm (Kontinen \& Ojala, 2010).

\subsection{Firm Age and Foreign Market Entry Modes}

Firm age is an essential contextual dimension in small business foreign market entry mode preference literature. The firm's age has been regularly used as a sampling criterion in particular for those studies focusing on small business that internationalize. Knight and Cavusgil (2004) observed the phenomenon of "born globals" or international new ventures, which are firms internationalizing right from or shortly after their birth. This distinguishes early internationalizing firms from companies that follow a slower and more incremental route to internationalization as suggested by Johansson and Vahlne (1977). The underlining assumption of the gradualist approach is that firms initiate their first international entry once they have a strong domestic market base, i.e. at an older age. Similarly Lejpras (2009) argued that the business strategy approach perceives a firm's international behavior as dependent on its resources and capabilities, as well as external conditions. It argues that as firm ages, it develops managerial and entrepreneurial competencies and accumulates knowledge and experience about the competitive environment. This can embolden the business to venture into foreign markets. Thus, Lejpras (2009) postulates that firm age should positively affect its involvement in foreign markets; the surprising find in his study however, was the negative influence of firm age on exporting. Sharma and Blomstermo (2003) however, suggested that the longer a firm delays to engage international activities, the harder it will be for it to grow internationally. Studies that look at international new ventures find that early and rapidly internationalizing firms often enter foreign markets by means of lower-commitment modes, such as through distributors or by means of exporting (e.g., Burgel \& Murray, 2000; Shrader, 2001). The studies also emphasize that firms that internationalize nearly from inception suffer from liabilities of newness as an additional burden in their foreign market entry mode choice (Burgel \& Murray, 2000; Zhou, Wu, \& Luo, 2007). On the other hand, studies (Autio, Sapienza, \& Almeida, 2000) emphasize that early and rapidly internationalizing firms enjoy some learning advantages of newness. These learning advantages of newness allows the firms to identify, value, select, and assimilate new knowledge faster than older companies that often suffer from inactivity and maintaining the status quo.

Zhou and $\mathrm{Wu}$ (2014) found in their study that internationalizing early positively contributes to firm performance in terms of sales growth, but not innovation and profitability. Haltiwanger, et al (2013) have also emphasized the importance of firm age when considering firm growth dynamics, one of which includes internationalization. Though Carr, Haggard, Hmieleski and Zahra (2010) confirmed that the relationship is uncertain in their study. They (Carr, et al, 2010) pointed out that resources and capabilities appear to be age dependent; with younger companies having limited resources and fewer capabilities than their established counterparts. Kaynak and Kuan (1993) report a positive relationship between the two variables. Autio et al. (2000) argues conversely that the age of a firm hampers the ability to compete successfully in international environments, pointing out that early internationalization might reinforce an environment of constant experimentation and an urge to venture across borders (Cohen and Levinthal 1990). The evidence on the relationship between firm age and mode of internationalization is mixed

However, on the basis of literature reviewed, exporting and licensing which are among some of the most common and popular mode of internationalization is adopted by all firms regardless of age, while on the other hand modes of internationalization such as joint ventures and foreign direct investments call for more maturity in terms of size, age, experiences and resources (Carr, et al, 2010). Hill, et al (1990), Johansson and Vahlne (1977), Johansson and Wiedersheim-Paul, 1975), Vahlne \& Wiedersheim-Paul (1973) and other scholars that subscribe to the behavioral theories of internationalization postulated that internationalizations is an incremental, step by step, stage process which calls of increased commitment of resources as a business moves up the 'establishment chain'. This means that small businesses with their limited resources are relegated to the lower levels of commitment on the establishment chain such as exporting and licensing agreements (Kontinen \& Ojala, 2010; Carr, et al, 2010; Hill, et al, 1990). The following hypotheses can therefore be made on the basis of literature:

$\mathrm{H}_{1}$ : There is no significant difference between firm age and level of exporting

$\mathrm{H}_{2}$ : There is no significant difference between firm age and level of licensing

$\mathrm{H}_{3}$ : There is a significant difference between firm age and level of joint ventures

$\mathrm{H}_{4}$ : There is a significant difference between firm age and level of foreign direct investments 


\section{METHODOLOGY}

The study adopted a quantitative cross sectional design. The fact that Likert type data where merged into a single score/variable after they were collected and analyzed with statistical procedures makes it a quantitative method as stipulated by Creswell (2003). The study is also cross-sectional since significant data were acquired from respondents at one specific point in time in order to save on the time and cost concerns (Creswell, 2003), this design was adopted due to the fact that it makes data collection faster (Creswell, 2003). A minimum sample size of 400 was arrived at using slovin's formula, 600 questionnaire where sent out and 409 where retrieved. Rooks \& Sserwanga (2009) argued that a robust sample is hard to acquire in studies involving small businesses in Uganda, because most of them are not registered. Purposive sampling was utilized to select the respondents based on these criteria: (i) the administrative divisions of Kampala: Kampala Central, Kawempe, Nakawa, Makindye and Lubaga; (ii) Legally registered small enterprises; and (iii) employs 5 or more and 50 or less people. Though the sampling units were the businesses, the owner/managers were the units of enquiry. Using range scale: 3.26-4.00 - High level, 2.51-3.25 -Moderate, 1.76-2.50 -Low, and 1.00-1.75 -Very Low, the level of mode of entry was interpreted, ANOVA was used to explore differences.

\section{RESULTS AND DISCUSSIONS}

A majority of the business owners are male, 258 or $63.08 \%$. This highlights the traditionally dominant role of men in Ugandan society and business generally; it also points to the resilient role of women and their gradual progression in the business arena (151 or 36.92\%). Most of the business owner's age were from 20-59 years and above, but more business owners were concentrated between the age range of 20-39 years old, this concentration indicates that most business owners are in early adulthood accounting for $235(57.46 \%)$ of the respondents followed by those in middle adulthood (155 or 37.90\%). Sole proprietorships made up a majority of $48.90 \%$ or 200 of the responding businesses, with Partnerships, 141 or $34.47 \%$ and (Limited) Companies were the least represented with 68 or $16.63 \%$. This may point out the fact that Sole proprietorships are easier to startup (and dissolve) and companies may be the most difficult to establish. A cumulative percentage of 92.17 of the businesses employ less than 30 people and only $2.93 \%$ or 12 exceed 49 employees (having 50 employees). Most businesses have 5 to 9 employees (178 or 43.52\%), followed by those employing 10 to 19, accounting for 156 or $38.1 \%$. Though in terms of employees, small businesses employee 5 to 50 employees, the facts point to fewer small businesses employing close to 50 employees and more employing closer to 5 employees. Industry/sector types consisting of cleaning services, construction, insurance, banking, agribusiness, textile, real estate, entertainment, security and petroleum accounting for $14.91 \%$ or 61 respondents; followed by the beauty/cosmetics which makes up $14.43 \%$ or 59 respondents; both the printing/publishing and office supplies sector accounted for the least represented respondents at $2.69 \%$ or 11 respondents. More than two third (2/3) of the businesses sampled are 10 years old or less (314) and 371 or $90.71 \%$ of the businesses have existed for less than 16 years. More businesses are concentrated with the age range of 6 to 10 years, 177 or $43.28 \%$ followed by those within the age range of 1 to 5 years which is 137 or $33.50 \%$. Overall most of the businesses in the several industry/sectors have only been in existence for the last 1 to 5 year (137) followed by those in businesses for 6 to 10 years (177).

Table 1: Levels of Mode of Entry Adopted (N=409)

\begin{tabular}{|l|c|c|c|c|c|}
\hline \multicolumn{1}{|c|}{ Mode Of Entry } & Mean & Std. Dev. & T Value & Interpretation & Rank \\
\hline Exporting & 1.611 & 1.086 & 1.483 & Very Low & 1 \\
\hline Licensing & 1.474 & 0.845 & 1.744 & Very Low & 3 \\
\hline Joint Venture & 1.518 & 0.916 & 1.657 & Very Low & 2 \\
\hline FDI TI & 1.445 & 0.850 & 1.700 & Very Low & 4 \\
\hline \multicolumn{1}{|c|}{ Total } & $\mathbf{1 . 5 1 2}$ & $\mathbf{0 . 9 2 4}$ & $\mathbf{1 . 6 3 6}$ & Very Low & \\
\hline
\end{tabular}

Table 1 confirms the fact that the level of internationalization and in particular the modes of entry are very low among the small businesses considered for the study. This finding could be explained by Crick (2007) who suggested that the difficulty of identifying sufficient representation in target export markets by the small businesses, along with finding an appropriate foreign market partner can be an impediment on internationalization. Orr (2006) concurred that several small businesses lack the competitive edge that could lead them to internationalize due to their emphasis on domestic key success factors rather than the international key success factors summed up with the failure to invest in opportunities for international experience and training. In spite of the very low (mean $=1.51$ ) levels overall, exporting among the small businesses ranked the highest (mean=1.61), though it was still very low. This can indicate the suggestions of Sousa and Tan (2015) that exporting is the first stage of internationalization adopted by various businesses. While Foreign Direct Investment $($ FDI $)$ ranked the lowest $($ mean $=1.45)$. This corroborates scholars such as Michalski (2015), 
Maeseneire \& Claeys (2007) and Lu \& Beamish (2001) who pointed out that, small businesses don't have the commitment in terms of resources needed to take on the more extensive levels of international such as FDI.

A one-way between-group analysis of variance (ANOVA) was carried out to explore the effect of firm age on respective levels of foreign market entry modes (exporting, licensing, joint venture and foreign direct investments). Firms are divided into six age groups (Group 1: $<5$ years, Group 2: age $\geq 6$ but $<10$, Group 3: age $\geq 11$ but $<15$, Group4: age $\geq 16$ but $<20$, Group 5: age $\geq 21$ but $<25$, and Group 6: age $\geq 26$.)

Table 2: Difference between Firm Age and Exporting

\begin{tabular}{|l|l|l|l|l|l|}
\hline & $\begin{array}{l}\text { Sum Of } \\
\text { Squares }\end{array}$ & Df & Mean Square & F & Sig. \\
\hline Between Groups & 2.126 & 5 & 0.425 & 0.358 & 0.877 \\
\hline Within Groups & 479.062 & 403 & 1.189 & & \\
\hline Total & 481.188 & 408 & & & \\
\hline
\end{tabular}

Table 2 confirms that there was no statistically significant difference at the $p>.05$ level in export levels for the six age groups $[F(5,403)=0.43, p=0.88]$. This therefore confirms the hypothesis: there is no significant difference between firm age and level of exporting. This finding supports that fact that exporting is the most widely used mode of internationalization across firms with little regard to size or experiences. This is due to the fact that exporting is easier to engage, requires less resource commitment and the risk are limited compared to other modes of internationalization (Carr, et al, 2010).

Table 3: Difference between Firm Age and Licensing

\begin{tabular}{|l|r|r|r|r|r|}
\hline & \multicolumn{1}{|c|}{$\begin{array}{l}\text { Sum Of } \\
\text { Squares }\end{array}$} & \multicolumn{1}{|c|}{ Df } & Mean Square & \multicolumn{1}{c|}{ F } & \multicolumn{1}{|c|}{ Sig. } \\
\hline Between Groups & 4.795 & 5 & 0.959 & 1.346 & 0.244 \\
\hline Within Groups & 287.185 & 403 & 0.713 & & \\
\hline Total & 291.980 & 408 & & & \\
\hline
\end{tabular}

There was no statistically significant difference at the $p>.05$ level in licensing levels for the six age groups $[F(5,403)=0.96, p=0.24]$ as confirmed by table 3 . Thus confirming the hypothesis: there is no significant difference between firm age and level of licensing. As with exporting licensing agreement are less costly and risky compared to more resource intense modes of internationalization (Carr, et al, 2010). This means it can be easily adopted by small and big firms, as well as old and young firms.

Table 4:Difference between Firm Age and Joint Venture

\begin{tabular}{|l|r|r|r|r|r|}
\hline & \multicolumn{1}{c|}{$\begin{array}{c}\text { Sum Of } \\
\text { Squares }\end{array}$} & \multicolumn{1}{c|}{ Df } & Mean Square & \multicolumn{1}{c|}{ F } & \multicolumn{1}{|c|}{ Sig. } \\
\hline Between Groups & 2.849 & 5 & 0.570 & 0.677 & 0.641 \\
\hline Within Groups & 339.264 & 403 & 0.842 & & \\
\hline Total & 342.112 & 408 & & & \\
\hline
\end{tabular}

Table 4 indicates there was no statistically significant difference at the $p>.05$ level in joint venture levels for the six age groups $[F(5,403)=0.68, p=0.64]$. This implies that the third hypothesis: there is a significant difference between firm age and level of joint ventures; is rejected. The belief was that older and more experienced firms would adopt joint venture as a means of internationalizing (Kaynak \& Kuan, 1993), however this has proved untrue in this study due to the fact that there was no difference between older and younger firms when it came to join ventures.

Table 5:Difference between Firm Age and Foreign Direct Investments

\begin{tabular}{|l|l|l|l|l|l|}
\hline & $\begin{array}{l}\text { Sum Of } \\
\text { Squares }\end{array}$ & Df & Mean Square & F & Sig. \\
\hline Between Groups & 2.073 & 5 & 0.415 & 0.570 & 0.723 \\
\hline
\end{tabular}




\begin{tabular}{|l|l|l|l|l|l|}
\hline Within Groups & 292.939 & 403 & 0.727 & & \\
\hline Total & 295.012 & 408 & & & \\
\hline
\end{tabular}

There was no statistically significant difference at the $p>.05$ level in foreign direct investment levels for the six age groups $[F(5,403)=0.57, p=0.72]$ as suggested by table 5 . This finding suggests the rejection of the fourth and final hypothesis which states: There is a significant difference between firm age and level of foreign direct investment. Similar to the findings for joint venture, the extensive commitment of resources and the high risk involved suggest that young firm would shy away from it (Carr, et al, 2010; Kaynak \& Kuan, 1993).

The contrary to conventional findings, table 4 and 5 could be explained by the fact that this study focused on small business and by nature they possess limited resources, with little regard to age to engage more resource intense modes of internationalization. It could therefore be emphasized that small business, generally do not have the propensity to adopt internationalization modes that call for extensive resources and high levels of risk, due to their risk averse nature (Kontinen \& Ojala, 2010).

\section{CONCLUSIONS AND RECOMMENDATIONS}

The conclusion can be drawn therefore that on the basis of age of the small businesses all the different modes of internationalization did not vary and that age difference did not contribute to the type/mode of internationalization among small businesses in Kampala, Uganda. Though by virtue of being small businesses, the modes of entry/internationalization that requires more resource commitments are off limits, such as foreign direct investments. However some small businesses can attempt joint ventures through partnering with others in order to pool resources and internationalize.

On the basis of the above findings and conclusions, the recommendation can be made that small businesses need to be encourage to firstly, take on internationalization at the very least at the less resource commitment level (e.g. exporting) and secondly, try to partner with other small businesses in order to embrace internationalization modes that call for more resource commitment (e.g. joint ventures). This will enable the small businesses reap the benefits of internationalization, some of which includes access to new markets, potential increase profit, potential growth opportunities and ensure both viability and longevity of the businesses (Osunsan \& Nowak, 2015; Daszkiewicz \& Wach, 2014; Kontinen \& Ojala, 2010).

\section{REFERENCE}

[1]. Arregle, J. L., Hébert, L., \& Beamish, P. W. (2006). Mode of International Entry: The Advantages of Multilevel Methods. Management International Review, 46(5), 597-618.

[2]. Autio E, Sapienza H.J, Almeida J.G. 2000. Effects of Age at Entry, Knowledge Intensity, and Imitability on International Growth. Academy Of Management Journal 43(5): 909-924.

[3]. Brouthers, K. D. (2002). Institutional, Cultural and Transaction Cost Influences On Entry Mode Choice and Performance. Journal of International Business Studies, 33(2), 203-221.

[4]. Brouthers, K. D., \& Hennart, J. F. (2007). Boundaries of the Firm: Insights from International Entry Mode Research. Journal of Management, 33(3), 395-425.

[5]. Brouthers, K. D., Brouthers, L. E., \& Werner, S. (1996). Dunning's Eclectic Theory and the Smaller Firm: The Impact of Ownership and Locational Advantages on the Choice of Entry-Modes in the Computer Software Industry. International Business Review, 5(4), 377-394.

[6]. Burgel, O., \& Murray, G. C. (2000). The International Market Entry Choices of Start-Up Companies in High Technology Industries. Journal of International Marketing, 8(2), 33-62.

[7]. Canabal, A., \& White, G. O. (2008). Entry Mode Research: Past and Future. International Business Review, 17(3), 267-284.

[8]. Carr, J. C., Haggard, K. S., Hmieleski, K. M., \& Zahra, S. A. (2010). A Study of the Moderating Effects of Firm Age at Internationalization on Firm Survival and Short-Term Growth. Strategic Entrepreneurship Journal, 4(2), 183-192.

[9]. Cateora \& Graham (2002), International Marketing, 11 Edition, Mcgraw-Hill

[10]. Cohen, W. M., \& Levinthal, D. A. (1990). Absorptive Capacity: A New Perspective on Learning and Innovation. Administrative Science Quarterly, 128-152.

[11]. Creswell, J.W. (2003). Research Design: Qualitative, Quantitative And Mixed Methods Approaches (2 $2^{\text {nd }}$ Ed). London: Sage.

[12]. Crick, D. (2007). UK SMEs' Motives for Internationalizing: Differences between Firms Employing Particular Overseas Market Servicing Strategies. Journal of International Entrepreneurship, (5), 11-23.

[13]. Daszkiewicz, N., \& Wach, K. (2014). Motives for Going International and Entry Modes of Family Firms in Poland. Journal of Intercultural Management, 6(2), 5-18. 
[14]. De Maeseneire, W., \& Claeys, T. (2007). SMEs. FDI and Financial Constraints, Vlerick Leuven Gent Management School Working Paper Series, 25.

[15]. Haltiwanger, J., Jarmin, R. S., \& Miranda, J. (2013). Who Creates Jobs? Small Versus Large Versus Young. Review of Economics and Statistics, 95(2), 347-361.

[16]. Hill, C. W., Hwang, P., \& Kim, W. C. (1990). An Eclectic Theory of the Choice of International Entry Mode. Strategic Management Journal, 11(2), 117-128.

[17]. Johanson, J., \& Vahlne, J. E. (1977). The Internationalization Process Of The Firm-A Model Of Knowledge Development And Increasing Foreign Market Commitments. Journal of International Business Studies, 8(1),23-32.

[18]. Johanson, J., \& Wiedersheim-Paul, F. (1975). The Internationalization of the Firm-Four Swedish Cases. Journal of Management Studies, 12(3), 305-323.

[19]. Jones, M. V., \& Coviello, N. E. (2005). Internationalization: Conceptualizing an Entrepreneurial Process of Behaviour in Time. Journal of International Business Studies, 36(3), 284-303.

[20]. Kärkkäinen, A. (2005). Selection Of International Market Entry Mode, Seminar In Business Strategy And International Business

[21]. Kaynak, E., \& Kuan, W. K. Y. (1993). Environment, Strategy, Structure, and Performance in the Context of Export Activity: An Empirical Study of Taiwanese Manufacturing Firms. Journal of Business Research, 27(1), 33-49.

[22]. Knight, G. A., \& Cavusgil, S. T. (2004). Innovation, Organizational Capabilities, and the Born-Global Firm. Journal of International Business Studies, 35(2), 124-141.

[23]. Kontinen, T., \& Ojala, A. (2010). The Internationalization of Family Businesses: A Review of Extant Research. Journal of Family Business Strategy, 1(2), 97-107.

[24]. Kotler, P., \& Keller, K. L. (2006). Marketing Management 12e. Upper Saddle River, N.J: Pearson Prentice Hall.

[25]. Leih, S. Teece, D. (2014), Market Entry Strategies, In D. Teece and M. Augier (Eds). Palgrave Encyclopedia of Strategic Management, London.

[26]. Lejpras, A. (2009). Essays on the Determinants of Firm Innovativeness, Performance, and Internationalization (Doctoral Dissertation, Frankfurt (Oder), Univ., Diss., 2009).

[27]. Lu, J. W. (2002). Intra- And Inter-Organizational Imitative Behavior: Institutional Influences on Japanese Firms' Entry Mode Choice. Journal of International Business Studies, 33(1), 19-37.

[28]. Lu, J. W., \& Beamish, P. W. (2001). The Internationalization and Performance of SMEs. Strategic Management Journal, 22(6-7), 565-586.

[29]. Maekelburger, B., Schwens, C., \& Kabst, R. (2012). Asset Specificity and Foreign Market Entry Mode Choice of Small and Medium-Sized Enterprises: The Moderating Influence of Knowledge Safeguards and Institutional Safeguards. Journal of International Business Studies, 43(5), 458-476.

[30]. Michalski, E. (2015). Foreign Market Entry Strategy, Oeconomia, 14(2), 107-117.

[31]. Nakos, G., \& Brouthers, K. D. (2002). Entry Mode Choice of SMEs in Central and Eastern Europe. Entrepreneurship Theory and Practice, 27(1), 47-63.

[32]. Orr, S. (2006) International Small Business Strategy: Is Practice Meeting the Challenge? , Proceedings of the 11th Annual Conference of Asia Pacific Decision Sciences Institute Hong Kong, June 14-18, (20),342-355.

[33]. Osunsan, O. K., Nowak, J., Mabonga, E., Pule, S., Kibirige, A. R., \& Baliruno, J. B. (2015). Firm Age and Performance in Kampala, Uganda: A Selection of Small Business Enterprises. International Journal of Academic Research in Business and Social Sciences, 1(5), 412-422.

[34]. Pan, Y. G., \& Tse, D. K. (2000). The Hierarchical Model of Market Entry Modes. Journal of International Business Studies, 31(4), 535-554.

[35]. Quer, D., Claver, E., \& Andreu, R. (2007). Foreign Market Entry Mode in the Hotel Industry: The Impact of Country-And Firm-Specific Factors. International Business Review, 16(3), 362-376.

[36]. Rooks, G. \& Sserwanga, A. (2008). Cognitive Consequences Of Business Shut Down. The Case of Ugandan Repeat Entrepreneurs. School Of Innovation Sciences, Eindhoven University Of Technology

[37]. Shama, A. (2000). Determinants of Entry Strategies of Us Companies into Russia, the Czech Republic, Hungary, Poland, and Romania. Thunderbird International Business Review, 42(6), 651-676.

[38]. Sharma, D. D., \& Blomstermo, A. (2003). The Internationalization Process of Born Globals: A Network View. International Business Review, 12(6), 739-753.

[39]. Shrader, R. C. (2001). Collaboration and Performance in Foreign Markets: The Case of Young High Technology Manufacturing Firms. Academy Of Management Journal, 44(1), 45-60.

[40]. Sousa, C. M., \& Tan, Q. (2015). Exit From A Foreign Market: Do Poor Performance, Strategic Fit, Cultural Distance, And International Experience Matter?. Journal of International Marketing, 23(4), 84104. 
[41]. Vahlne, J. E., \& Wiedersheim-Paul, F. (1973). Economic Distance: Model and Empirical Investigation. Export and Foreign Establishments, 81-159.

[42]. Wilkinson, I. F., \& Nguyen, V. (2003). A Contingency Model of Export Entry Mode Performance: The Role of Production and Transaction Costs. Australasian Marketing Journal (AMJ), 11(3), 44-60.

[43]. Zhou, L \& Wu, A. (2014). Earliness of Internationalization and Performance Outcomes: Exploring the Moderating Effects of Venture Age and International Commitment, Journal of World Business, (49), 132 -142 .

[44]. Zhou, L., Wu, W. P., \& Luo, X. (2007). Internationalization and the Performance of Born-Global SMEs: The Mediating Role of Social Networks. Journal of International Business Studies, 38(4), 673-690. 